\title{
A Practical Application of Scanning Electron Microscopy to Characterize a Fine - Grained Sulfide Gold Ore
}

\author{
L.R.P. de Andrade Lima*, and D. Hodouin*
}

*Dep. Mining, Metallurgy and Materials, Laval University, Quebec City, PQ, Canada, G1K 7P4

Gold ore processi ng makes use of comminution, sizing, gravity concentration, and dewatering operations, followed by cyanidation [1]. In a typical industrial plant many samples are taken from the various streams to mesure operating variables, as solid content, particle size , gold content, free cyanide and oxygen concentrations, and $\mathrm{pH}$. At times, either when the behavior of the gold minerals the cyanide consumers, as some copper minerals, have a negative impact on the overall plant profit or when the plant gold recovery unexp ectedly diminishes, ore or leach residuals samples are carefully analyzed to find the causes of the observed problems. In such situations, analyses by scanning electronic microscopic (SEM) associated with energy dissipation spectrometer (EDS), and secondary ion mass spectrometry (SIMS) are economically justified [2,3]. The invistigated material is a quartz-sulfide ore from the Abitibi region in Canada, which has a gold average concentration of $8 \mathrm{~g} / \mathrm{t}$, an average particle size of $80 \%<37 \mu \mathrm{m}$, and is fed to a cyanidation plant at a rate of $37 \mathrm{~kg} / \mathrm{s}$.

The usual sample preparation for SEM studies of fine -grained gold ore first consists of a preliminary gravity concentration of the gold particles by bromoform. Then the sink fraction is mounted with an epoxy resin $[2,3]$. However, this method does not permit to collect the small gold particles locked in the sulfides. Therefore, in this study, instead of gravity, a flotation concentration is used to collect gold, gold-alloys, and sulfide particles. The ore is initially screened, and 500g of the minus $37 \mu \mathrm{m}$ fraction used to concentrate the gold and the sulfide mineral particles by flotation with $91 \mathrm{~g} / \mathrm{t}$ of potassium amyl-xanthate as a collector at $\mathrm{pH} 8.6$ (set with potassium carbonate). This material was dried, mixed with an epoxy resin, mounted in lames, polished, and coated with a thin layer of carbon to make the surfaces electrically conducting. Facilities in the Microanalyses Laboratory at Laval University were used for SEM and EDS measurements.

Some backscattered electrons images are illustrated in Fig. 1, Figure 1A shows the original samples containing mainly quartz particles (dark), and some sulfide particles (light). Figure 1B shows the ore concentrated by flotation with quartz particles (dark), sulfide particles (lig ht), and some heavy particles as silver, lead, copper, and gold (white). The others images exhibit free gold grain (C),

large free gold-silver-tellurium grain (D), gold grain locked in an iron -sulfide particle (E), and goldsilver grain partially locked in an iron-sulfide particle (F). Fig. 2 presents the distribution of the gold size of the grains collected, which has the predominance of small particles of 2 and $3 \mu \mu \mathrm{m}$, and indicates that ore concentration by flotation is able to collect gold grains as big as $30 \mu \mathrm{m}$ [4].

References

[1] K.J. Henley, Minerals Sci. Engng. 7(4) (1975) 289.

[2] J.L. Jambor and D.J. Vaughhan, Advanced Microscopic Studies of Ore Minerals, Mineral. Assoc. Can. Short Course 17, 1990.

[3] R. Lastra et al, Trans. Instn. Min. Metall. 108 (1999) C75.

[4] This research was supported by CNPq, and Federal University of Bahia (Brazil), and Quebec Government. Doyon Mine is gratefully acknowledged for samples supply. 

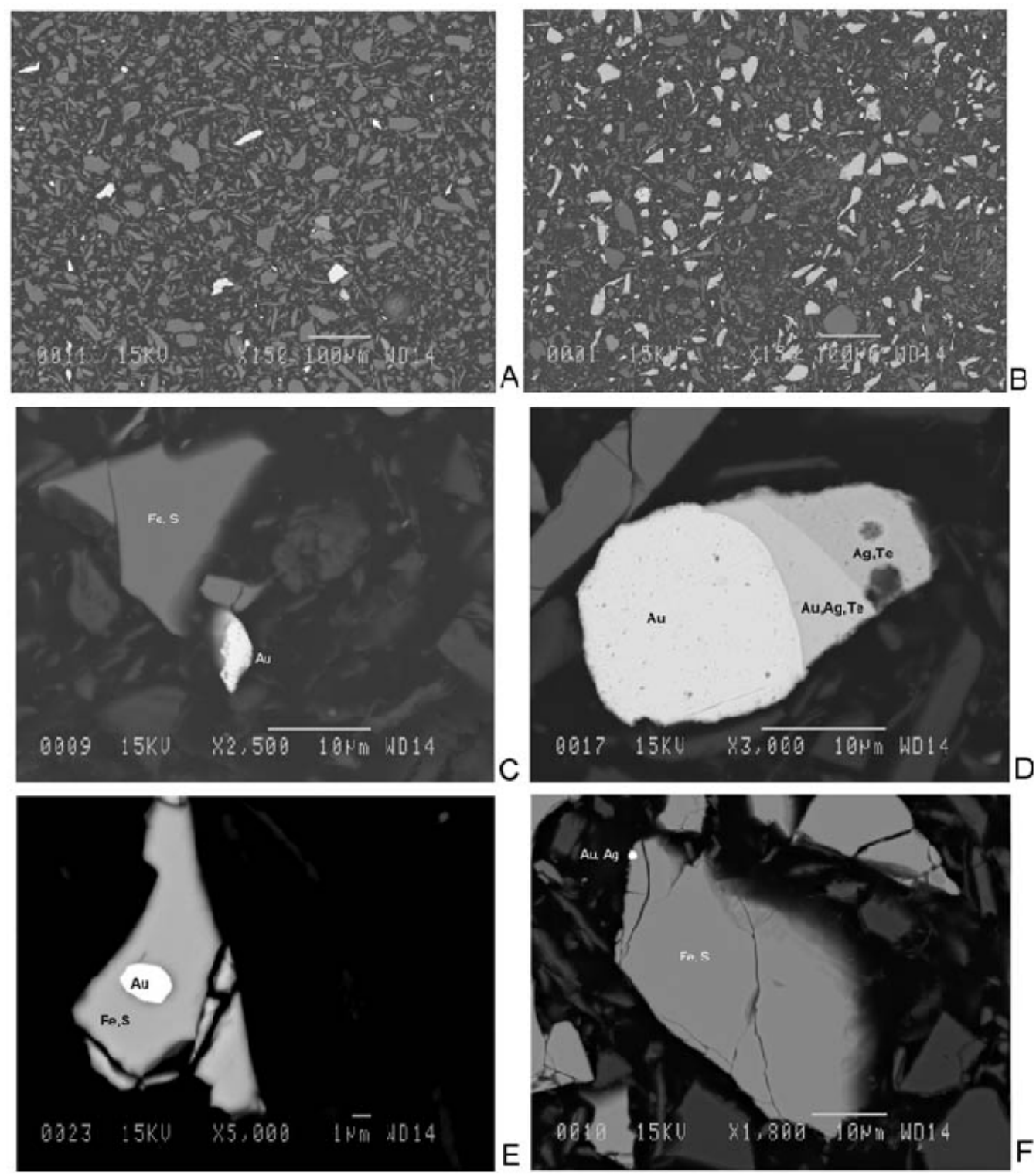

FIG. 1. Backscattered electrons images of the gold ore: a) original ore rich in q uartz (dark grains) and some sulfides minerals (light grains), b) flotation concentrate fraction rich in sulfides minerals, c) free gold grain, d) large free gold -silver-tellurium grain, e) gold locked in an iron -sulfide mineral grain, f) gold-silver partially locked in an iron-sulfide mineral grain.

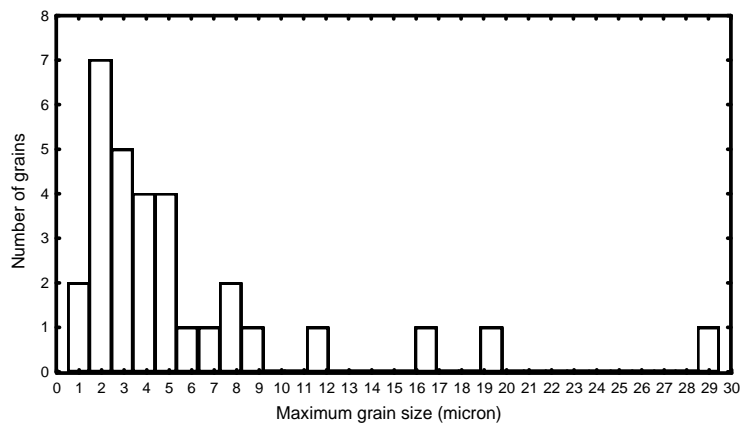

FIG. 2. Gold grains size distribution 